\title{
Comparative Study of Succinylcholine with Different Doses of Rocuronium Bromide for Tracheal Intubation during General Anaesthesia
}

\author{
Rajesh Panda ${ }^{1}$, Priyadarshani Padhihari ${ }^{2}$, Jack Meitei ${ }^{3}$, N. Ratan Singh ${ }^{4}$, \\ Kishore Kumar Behera ${ }^{5}$, Subrat Kumar Nayak ${ }^{6}$ \\ ${ }_{1,3,4,5,6}$ (Department Of Anaesthesiology, Regional Institute Of Medical Sciences, Imphal, India) \\ ${ }^{2}$ (Department Of Community Medicine, Regional Institute Of Medical Sciences, Imphal, India)
}

\begin{abstract}
:
Background and objective: Tracheal intubation is one of the best methods of securing a patient airway. Though many non-depolarising muscle relaxants (NDMRs) like atracurium besylate, vecuronium bromide and mivacurium chloride were introduced, they however have not matched the timing and intubating conditions produced by succinylcholine. The new NDMR drug rocuronium bromide became the first competitor for succinylcholine as it produces excellent cardiovascular stabilityand is devoid of the adverse effects that are seen with succinylcholine. Hence, the present study was undertaken to compare the intubating conditions, hemodynamic changes and adverse effects of using injection succinylcholine $1 \mathrm{mg} / \mathrm{kg}$ with two doses of injection rocuronium bromide $0.6 \mathrm{mg} / \mathrm{kg}$ and $1 \mathrm{mg} / \mathrm{kg}$ body weight during general anaesthesia in adult patients.

Methodology: The study population consisted of 90 patients aged between 18-60 years posted for various elective surgeries requiring general anaesthesia. Study population was randomly divided into 3 groups with 30 patients in each sub group. Group A received injection succinylcholine $1 \mathrm{mg} / \mathrm{kg}$ body weight and intubation, group B received injection rocuronium bromide $0.6 \mathrm{mg} / \mathrm{kg}$ body weight and group C received injection rocuronium bromide $1 \mathrm{mg} / \mathrm{kg}$ body weight and intubation attempted at 60 seconds. Intubating conditions were assessed at 60 seconds based on the scale adopted by Toni Magorian et al. 1993.

Results: It was found that succinylcholine $1 \mathrm{mg} / \mathrm{kg}$ body weight and rocuronium bromide $1 \mathrm{mg} / \mathrm{kg}$ body weight produced excellent intubating condition in $96.7 \%$ and $93.3 \%$ of the patients, respectively whereas rocuronium bromide $0.6 \mathrm{mg} / \mathrm{kg}$ produced excellent intubating condition in only $50 \%$ of the patients and the difference was statistically significant. Rocuronium bromide $0.6 \mathrm{mg} / \mathrm{kg}$ produced significant increase in heart rate, systolic blood pressure, diastolic blood pressure from baseline as compared to succinylcholine $1 \mathrm{mg} / \mathrm{kg}$ and rocuronium bromide $1 \mathrm{mg} / \mathrm{kg}$, post induction.

Conclusion: Thus, from the present study, it is clear that Rocuronium is a safe, haemodynamically stable and good alternative for succinylcholine for endotracheal intubation at 60 seconds and can be used for safe intubation, if there is no anticipation of difficult intubation.
\end{abstract}

Keywords: Anaesthesia, Rocuronium bromide, Succinylcholine, Tracheal intubation

\section{Introduction}

The primary role of anaesthesiologists is to secure and maintain a patent airway. Tracheal intubation is one of the best methods of securing a patient airway.

Succinylcholine (Sch), a depolarising agent was introduced by Thesleff and Foldes in 1952, which changed anaesthetic practice drastically and was considered the gold standard for tracheal intubation.[1,2,3] Its rapid onset of effect and ultrashort duration of action permitted rapid endotracheal intubation.[4] But all did not go well for succinylcholine when its adverse effects started surfacing especially fasciculations[5], hyperkalemia[6,7], post-operative muscle pains[8], rise in intragastric, intracranial and intraocular pressure.[9]

The aim of research on neuromuscular drugs was to have a nondepolarising muscle relaxant (NDMR), which is like succinylcholine but without its side effects.[10] Though many non-depolarising muscle relaxants (NDMRs) like atracurium besylate, vecuronium bromide and mivacurium chloride were introduced, they however have not matched the timing and intubating conditions produced by succinylcholine.[10] The new NDMR drug rocuronium bromide introduced in 1994 became the first competitor for succinylcholine.[11] Rocuronium bromide when given in two to three times the $\mathrm{ED}_{95}$ (effective dose), is said to produce excellent to good intubating conditions in 60 seconds similar to those obtained with succinylcholine but with excellent cardiovascular stability.[10] Further rocuronium bromide being a nondepolarising agent is devoid of the adverse effects that are seen with succinylcholine.[10] 
Hence, the present study was undertaken to compare the intubating conditions, hemodynamic changes and adverse effects of using injection succinylcholine $1 \mathrm{mg} / \mathrm{kg}$ with two doses of injection rocuronium bromide $0.6 \mathrm{mg} / \mathrm{kg}$ and $1 \mathrm{mg} / \mathrm{kg}$ body weight during general anaesthesia in adult patients.

\section{Materials And Methods}

The study was a prospective randomized double-blind controlled trial conducted among all the patients undergoing general anaesthesia fulfilling the inclusion criteria which was ASA grade I/II, either sex, age group between 18-60 years and Mallampatti grade I and II. Patients with ASA grade III/IV, Mallampatti grade III/IV, increased risk of aspiration, having contraindications to suxamethonium and rocuronium, history of drug and alcohol abuse, hepatic and renal impairment, neuromuscular diseases, BMI $>30$ and anticipated difficult intubation were excluded from the study. A sample size of 26 in each group was determined and it was rounded to 30 patients in each group. Patients were randomly allocated to three groups with equal number of patients in each group according to computer generated randomization list.

Group A received injection succinylcholine $1 \mathrm{mg} / \mathrm{kg}$ body weight and intubation, group B received injection rocuronium bromide $0.6 \mathrm{mg} / \mathrm{kg}$ body weight and group $\mathrm{C}$ received injection rocuronium bromide $1 \mathrm{mg} / \mathrm{kg}$ body weight and intubation attempted at 60 seconds. Assesment of intubating conditions was done according to a qualitative scoring system described by Cooper et al.[12] Table 1 shows criteria and score of intubating conditions assigned to the patients.

Table 1. Criteria and score of intubating conditions

\begin{tabular}{|l|l|l|}
\hline Jaw relaxation & Vocal Cords & Response to intubation \\
\hline Poor (impossible) $=0$ & Closed $=0$ & Severe coughing $=0$ \\
\hline Minimal (difficult) $=1$ & Closing $=1$ & Mild coughing $=1$ \\
\hline Moderate (fair) $=2$ & Moving $=2$ & Slight diaphragm movement $=2$ \\
\hline Good(easy) $=3$ & Open $=3$ & None $=3$ \\
\hline
\end{tabular}

Intubating conditions in all the patients were graded as excellent, good, fair, poor after calculating scores of jaw relaxation, vocal cords and response to intubation as shown in Table 2.

Table 2. Grading of intubation

\begin{tabular}{|c|c|}
\hline Intubating condition & Score \\
\hline Excellent & $8-9$ \\
\hline Good & $6-7$ \\
\hline Fair & $3-5$ \\
\hline Poor & $0-2$ \\
\hline
\end{tabular}

The excellent and good intubating conditions were taken as acceptable where as the fair and poor intubating condition were considered as unacceptable. In the perioperative period, side-effects and complications, if any was noted in all patients.

Preanaesthetic evaluation was done in all patients scheduled for elective surgeries. Detailed history, physical examination and basic investigation were performed in all patients. On arrival in the operation theatre, electro-cardiography, non-invasive blood pressure, pulse oximetry, capnography were monitored. A 20-gauge intravenous catheter was placed for administration of intravenous fluids and drugs.

All drugs were prepared by an anaesthetiologist not involved in the study to keep the study investigation blinded. Pre-oxygenation using a tight-fitting mask was performed for 3 min with $100 \%$ oxygen. Just before induction every patient were premedicated with injection glycopyrolate $0.2 \mathrm{mg}$ intravenously. Anaesthesia was induced with inj. propofol $3 \mathrm{mg} / \mathrm{kg}$ till the eyelash reflex is lost and then administration of the designated dose of study drug was done. Laryngoscopy was attempted for facilitation of endotracheal intubation 60 seconds after the administration of either of the respective drug.

Blood pressure (BP), heart rate (HR) and peripheral oxygen saturation $(\mathrm{SpO} 2)$ were recorded before induction of anaesthesia, at induction and post-induction (1 min after tracheal intubation). In the event of bradycardia (HR< 50 beats per min), inj atropine was administered. In the event of a decrease in mean arterial pressure (MAP) $>25 \%$, mephentermine was administered in $3 \mathrm{mg}$ increments. Adverse events such as laryngospasm, bronchospasm, masseter spasm or muscle rigidity were recorded. After tracheal intubation, anaesthesia was maintained with balanced technique of using nitrous oxide, oxygen, isoflurane and systemic analgesics.

The collected data were entered and analyzed in SPSS (IBM) version 21. Summarization of data for frequency distribution of variables of interest were carried out by using descriptive statistics such as mean, 
standard deviation and percentages. Chi-square test, Fisher's exact test and ANOVA with post hoc analysis were used to test the association. P-value of less than 0.05 was taken as statistically significant.

Ethical approval was obtained from the Institutional Ethics Committee, RIMS, Imphal before the beginning of the study. Written informed consent were taken from the participants and their participation was completely voluntary and the right for refusal to participate in the study was respected.

\section{Results}

Patients in all the five groups were comparable with respect to age, weight, and ASA physical status (Tables 3).

Table 3. Background characteristics of the patients

\begin{tabular}{|l|c|c|c|c|}
\hline Background characteristics & Group A & Group B & Group C & p-value \\
\hline Age in yrs (mean \pm SD) & $41.5 \pm 10.6$ & $34.7 \pm 10.3$ & $38.3 \pm 10.6$ & 0.302 \\
\hline Body weight in kg (mean \pm SD) & $56.9 \pm 5.9$ & $57.8 \pm 5.3$ & $57.2 \pm 5.1$ & 0.807 \\
\hline Male n(\%) & $6(20.0)$ & $7(23.3)$ & $5(16.7)$ & \multirow{2}{*}{0.812} \\
\hline Female n (\%) & $24(80.0)$ & $23(76.7)$ & $25(83.3)$ & \\
\hline ASA grade I (\%) & $16(53.3)$ & $15(50.0)$ & $12(40.0)$ & \multirow{2}{*}{0.561} \\
\hline ASA grade II (\%) & $14(46.7)$ & $15(50.0)$ & $18(60.0)$ & \\
\hline Mallampati grade I (\%) & $16(53.3)$ & $11(36.7)$ & $12(40.0)$ & \multirow{2}{*}{0.387} \\
\cline { 1 - 3 } Mallampati grade II (\%) & $14(46.7)$ & $19(63.3)$ & $18(60.0)$ & \\
\hline
\end{tabular}

Succinylcholine $1 \mathrm{mg} / \mathrm{kg}$ body weight and rocuronium bromide $1 \mathrm{mg} / \mathrm{kg}$ body weight produced excellent intubating condition in $96.7 \%$ and $93.3 \%$ of the patients, respectively whereas rocuronium bromide $0.6 \mathrm{mg} / \mathrm{kg}$ produced excellent intubating condition in only $50 \%$ of the patients and the difference was statistically significant (Table 4).

Table 4. Distribution of patients in relation to their Intubating condition score

\begin{tabular}{|l|c|c|c|c|}
\hline $\begin{array}{l}\text { Intubating condition } \\
\text { Score }\end{array}$ & $\begin{array}{c}\text { Group A } \\
\mathrm{n}(\%)\end{array}$ & $\begin{array}{c}\text { Group B } \\
\mathrm{n}(\%)\end{array}$ & $\begin{array}{c}\text { Group C } \\
\mathrm{n}(\%)\end{array}$ & p-value \\
\hline Excellent & $29(96.7)$ & $15(50.0)$ & $28(93.3)$ & \multirow{2}{*}{0.000} \\
\hline Good & $1(3.3)$ & $13(43.3)$ & $2(6.7)$ & \\
\hline Fair & 0 & $2(6.7)$ & 0 & \\
\hline
\end{tabular}

Rocuronium bromide $0.6 \mathrm{mg} / \mathrm{kg}$ produced significant increase in heart rate, systolic blood pressure, diastolic blood pressure from baseline as compared to succinylcholine $1 \mathrm{mg} / \mathrm{kg}$ and rocuronium bromide $1 \mathrm{mg} / \mathrm{kg}$, post induction (Table 5).

Table 5. Heart rate, systolic blood pressure, diastolic blood pressure and $\mathrm{SpO}_{2}$ in three groups pre-induction and post-induction

\begin{tabular}{|c|c|c|c|c|c|}
\hline Groups & $\begin{array}{c}\text { Pre-induction } \\
\text { Mean } \pm \text { SD }\end{array}$ & $\begin{array}{c}\text { Post-induction } \\
\text { Mean } \pm \text { SD }\end{array}$ & Increase & $\begin{array}{c}\text { Percentage } \\
\text { increase }\end{array}$ & $\mathrm{p}$-value \\
\hline \multicolumn{6}{|c|}{ Heart rate (beats/min) } \\
\hline Group A & $79.4 \pm 4.4$ & $112.5 \pm 6.1$ & 33.1 & 41.6 & \multirow{3}{*}{0.02} \\
\hline Group B & $78.2 \pm 3.2$ & $116.1 \pm 7.4$ & 37.9 & 48.4 & \\
\hline Group C & $77.3 \pm 3.1$ & $111.6 \pm 5.8$ & 34.3 & 44.3 & \\
\hline \multicolumn{6}{|c|}{ Systolic blood pressure $(\mathrm{mm}$ of $\mathrm{Hg})$} \\
\hline Group A & $121.67 \pm 3.1$ & $131.13 \pm 2.7$ & 9.46 & 7.7 & \multirow{3}{*}{0.000} \\
\hline Group B & $121.60 \pm 3.4$ & $134.87 \pm 3.2$ & 13.27 & 10.9 & \\
\hline Group C & $121.53 \pm 3.2$ & $131.40 \pm 2.6$ & 9.87 & 8.1 & \\
\hline \multicolumn{6}{|c|}{ Diastolic blood pressure $(\mathrm{mm}$ of $\mathrm{Hg})$} \\
\hline Group A & $78.3 \pm 2.4$ & $84.4 \pm 2.8$ & 6.1 & 7.7 & \multirow{3}{*}{0.001} \\
\hline Group B & $78.0 \pm 2.2$ & $87.2 \pm 2.6$ & 9.2 & 11.8 & \\
\hline Group C & $78.1 \pm 2.8$ & $85.5 \pm 3.0$ & 7.4 & 9.5 & \\
\hline \multicolumn{6}{|l|}{$\mathrm{SpO}_{2}(\%)$} \\
\hline Group A & $98.9 \pm 1.2$ & $99.5 \pm 0.5$ & 0.6 & 0.6 & \multirow{3}{*}{0.878} \\
\hline Group B & $98.7 \pm 1.2$ & $99.5 \pm 0.6$ & 0.8 & 0.8 & \\
\hline Group C & $99.0 \pm 1.1$ & $99.6 \pm 0.5$ & 0.6 & 0.6 & \\
\hline
\end{tabular}

Adverse effects of the drugs noticed during the study were muscle fasciculation and sore throat and hoarseness of voice (Table 6). There was significantly more side effects in succinylcholine group as compared to rocuronium group as shown in Table 7. 
Table 6: Reported adverse effects

\begin{tabular}{|l|c|c|c|}
\hline Adverse effects & $\begin{array}{c}\text { Group A } \\
\mathrm{n}(\%)\end{array}$ & $\begin{array}{c}\text { Group B } \\
\mathrm{n}(\%)\end{array}$ & $\begin{array}{c}\text { Group C } \\
\mathrm{n}(\%)\end{array}$ \\
\hline Muscle fasciculation & $9(30.0)$ & 0 & 0 \\
\hline $\begin{array}{l}\text { Sore throat and hoarseness of } \\
\text { voice }\end{array}$ & $1(3.3)$ & $2(6.6)$ & $1(3.3)$ \\
\hline
\end{tabular}

Table 7. Comparison of side effect between succinylcholine and rocuronium group*

\begin{tabular}{|c|c|c|c|}
\hline Side effects & $\begin{array}{c}\text { Succinylcholine group } \\
\text { N (\%) }\end{array}$ & $\begin{array}{c}\text { Rocuronium group } \\
\text { N (\%) }\end{array}$ & p-value \\
\hline Yes & $10(33.3)$ & $3(5.0)$ & \multirow{2}{*}{0.001} \\
\hline No & $20(66.7)$ & $57(95.0)$ & \\
\hline
\end{tabular}

* Group B and C clubbed

\section{Discussion}

\subsection{Intubating conditions}

In the present study involving comparison of succinylcholine $1 \mathrm{mg} / \mathrm{kg}$ body weight with rocuronium bromide $0.6 \mathrm{mg} / \mathrm{kg}$ body weight and $1 \mathrm{mg} / \mathrm{kg}$ body weight for endotracheal intubation in adult patients. It was noted that succinylcholine $1 \mathrm{mg} / \mathrm{kg}$ body weight and rocuronium $0.9 \mathrm{mg} / \mathrm{kg}$ produced excellent intubating conditions in $96.7 \%$ and $93.3 \%$ of the patients, respectively while rocuronium bromide $0.6 \mathrm{mg} / \mathrm{kg}$ body weight produced excellent intubating conditions in only $50 \%$ of cases. The present study was comparable with study of Penchalaiah $\mathrm{C}$ et al.[13] Thus increasing the dose of rocuronium bromide from $0.6 \mathrm{mg} / \mathrm{kg}$ to $1 \mathrm{mg} / \mathrm{kg}$ body weight increased the incidence of excellent intubating conditions. The study results were comparable to Toni Magorian et al,[14] Cooper et al[15] and Puhringer et al[16] and K. C. McCourt et al.[17]

\subsection{Cardiovascular changes}

There was a rise in mean heart rate by $41.6 \%, 48.4 \%$ and $44.3 \%$ following administration of succinylcholine $1 \mathrm{mg} / \mathrm{kg}$ body weight, rocuronium $0.6 \mathrm{mg} / \mathrm{kg}$ body weight and $1 \mathrm{mg} / \mathrm{kg}$ body weight, one minute following intubation, respectively. There was significant increase in heart rate from baseline after 1 minute in rocuronium $0.6 \mathrm{mg} / \mathrm{kg}$ group than rocuronium $1 \mathrm{mg} / \mathrm{kg}$ and succinylcholine $1 \mathrm{mg} / \mathrm{kg}$ group. These findings were similar to those observed by Misra M et al,[18] Bhale P et al,[19] Gupta et al,[20] Somani M et al.[21]

There was increase in systolic blood pressure by $7.7 \%, 10.9 \%$ and $8.1 \%$ from pre induction value following administration of succinylcholine $1 \mathrm{mg} / \mathrm{kg}$ body weight, rocuronium $0.6 \mathrm{mg} / \mathrm{kg}$ and $1 \mathrm{mg} / \mathrm{kg}$ body weight one minute following intubation, respectively. There was significant increase in systolic blood pressure from baseline after 1 minute in rocuronium $0.6 \mathrm{mg} / \mathrm{kg}$ group than in rocuronium $1 \mathrm{mg} / \mathrm{kg}$ and succinylcholine group. There was a similar increase in diastolic blood pressure by $7.7 \%, 11.8 \%$ and $9.3 \%$ from pre induction value following administration of succinylcholine $1 \mathrm{mg} / \mathrm{kg}$ body weight, rocuronium $0.6 \mathrm{mg} / \mathrm{kg}$ and $1 \mathrm{mg} / \mathrm{kg}$ body weight one minute following intubation, respectively. Similar findings were observed by Misra $\mathrm{M}$ et al,[18] Bhale P et al,[19] Gupta S et al[20] and Somani M et al.[21]

There was significant increase in diastolic blood pressure from baseline after 1 minutes in rocuronium $0.6 \mathrm{mg} / \mathrm{kg}$ group than rocuronium $1 \mathrm{mg} / \mathrm{kg}$ and succinylcholine $1 \mathrm{mg} / \mathrm{kg}$ group. Similar findings were observed by Misra M et al[18] and Somani M.[21] There was no significant difference seen in mean saturation of oxygen from baseline to post induction in the groups which is comparable to Marsch A.[22]

\subsection{Side effects}

Muscle fasciculations were seen in succinylcholine group (30\%). Shukla A et al[23] had also reported only muscle fasciculations in succinylcholine group in $95 \%$ of patients. Sore throat and hoarseness of voice were reported in succinylcholine $1 \mathrm{mg} / \mathrm{kg}$ group $(3.3 \%)$, rocuronium $0.6 \mathrm{mg} / \mathrm{kg}$ group (6.6\%) and rocuronium 1 $\mathrm{mg} / \mathrm{kg}$ group $(3.3 \%)$. No patient in succinylcholine and rocuronium group had any signs of histamine release (e.g. flushing, rash, bronchospasm).

\section{Conclusion}

Rocuronium $1 \mathrm{mg} / \mathrm{kg}$ is a safe, haemodynamically stable and good alternative for succinylcholine 1 $\mathrm{mg} / \mathrm{kg}$ for endotracheal intubation at 60 seconds and can be used for safe intubation, if there is no anticipation of difficult intubation. There was increase in heart rate, systolic blood pressure and diastolic blood pressure after 60 seconds of administration of drugs in all the three groups but the maximum increase was with rocuronium 0.6 $\mathrm{mg} / \mathrm{kg}$ and least increase with succinylcholine $1 \mathrm{mg} / \mathrm{kg}$. The most common side effects of the drugs in this study were muscle fasciculation in succinylcholine group and sore throat and hoarseness of voice in all the three groups but these were mild and safe-limiting in nature. 


\section{References}

[1]. Foldes FF, McNall PG, Borrego-Hinojosa JM, Succinylcholine, a new approach to muscular relaxation in anaesthesiology, N Engl J Med, 247, 1952, 596-600.

[2]. Thesleff S, Farmakologisks och kliniska forsook mod L.T.I.(O,O- succinylcholine jodid), Nord Med,46, $1951,1045$.

[3]. Hina Khurshid, Khawer Muneer, Shabir A Wani, A comparative study of intubating conditions using succinylcholine and two doses of rocuronium, Int J Adv Res, 3(5), 2015, 1152-1159.

[4]. Barash PG, Cullen BF, Stoelting RK, Handbook of Clinical Anesthesia (Lippincott Williams \& Wilkins, 2006).

[5]. Laurin EG, Sakles JC, Panacek EA, Rantapaa AA, Redd J, A comparison of succinylcholine with rocuronium for rapid sequence induction of emergency department patients, Acad Emerg Med, 7(12), 2000, 136-139.

[6]. Tolmie JD, Joyce TH and Mitchell, Succinylcholine danger in burned patient, Anesthesiology, 28, 1967,467

[7]. Collier CB, Suxamethonium pains and early electrolyte changes, Anesthesia, 33, 1978, 454

[8]. Ferres CJ, Mirakhur RK, Craig HJ, Browne ES, Clark RS, Pretreatment with vecuronium as a prophylactic against post suxamethonium muscle pain, Br J Anaesth, 55, 1983, 735.

[9]. Cook DR, Can succinylcholine be abandoned?, Anaesth Analg, 90, 2000, S2-S26.

[10]. Sasidharan Nair M, Sweetline Subha M, Sreejith H, Comparison of rocuronium bromide and succinylcholine chloride for use during rapid sequence intubation in adult patients, International Journal of Biomedical Research, 7(6), 2016, 365-371.

[11]. Kotambkar V, Tuljapure S, Comparison of intubating conditions of succinylcholine and rocuronium, International Journal of Recent Research in Life Sciences, 2(2), 2015, 35-39.

[12]. Cooper R, Mirakhur RK, Clarke RS, Boules Z, Comparison of intubating conditions after administration of Org 9426(rocuronium) and suxamethonium, Br J Anaesth, 69, 1992, 269-273.

[13]. Penchalaiah C, Babu NJ, Kumar T, Comparison of rocuronium bromide and succinylcholine chloride for use during rapid sequence intubation in adults, J of Evidence Based Med \& Hlthcare, 2(32), 2015, 4796-4806.

[14]. Magorian T, Flannery KB, Miller RD, Comparison of rocuronium, succinylcholine and vecuronium for rapid sequence induction of anaesthesia in adult patients, Anaesthesiology, 79, 1993, 913-918.

[15]. Cooper R, Mirakhur RK, Maddineni VR, Neuromuscular effects of rocuronium bromide during fentanyl and halothane anaesthesia, Anaesthesia, 48, 1993, 103-105.

[16]. Puhringer FK, Karin S, Khuenl-Brady, Koller J, Mitterschiffthaler G, Evaluation of endotracheal intubating conditions of rocuronium and succinylcholine in outpatient surgery, Anaesthesia Analgesia, 75, 1992, 37-40.

[17]. McCourt KC, Salmela L, Mirakhur RK, Carroll M, Rout GJ, Comparison of rocuronium and suxamethonium for use during rapid sequence induction of anaesthesia, Anesthesia, 53, 1998, 867-871.

[18]. Misra MN, Agarwal M, Pandey RP, Gupta A, A comparative study of rocuronium, vecuronium and succinylcholine for rapid sequence induction of anaesthesia, Indian J. Anaesth, 49(6), 2005, 469-473.

[19]. Bhale P, Bhandari N, Kumaran SP, Joshi R, Comparison of suxamethonium with rocuronium for endotracheal Intubation, International Journal of Recent Trends in Science And Technology, 9(1), 2013, 52-56.

[20]. Shobhana G, Kirubahar R, A comparative study of intubating conditions of rocuronium bromide and suxamethonium in adult patients, Anesth Essays Res, 4, 2010, 15-19.

[21]. Somani M, Sharma P, Sachdev S, Mathur V, Chaturvedi S, A comparitive study between vecuronium and rocuronium for intubating condition and hemodynamic changes, IOSR Journal of Dental and Medical Sciences, 13(6), 2014, 33-39.

[22]. Marsch SC, Steiner L, Bucher E, Pargger H, Schumann M, Aebi T, Hunziker PR and Siegemund M, Succinylcholine versus rocuronium for rapid sequence intubation in intensive care: a prospective, randomized controlled trial, Critical Care, 15, 2011, R199.

[23]. Shukla Aparna DK, Sharma MS, Comparative evaluation of haemodynamic effects and intubating conditions after administration of ORG 9426 (Rocuronium) and Succinylcholine, Indian J Anaesth, 48, 2004, 476-479. 